\title{
JUAL BELI DALAM \\ PANDANGAN ISLAM
}

\author{
Oleh: Shobirin
}

\begin{abstract}
Selling (business) is the exchange of wealth on the basis of mutual willing and the joint agreement. There are four Perversions, namely; (1) Marriage (ijab qobul) (2) the prescribed is run (subject) البيقان (3) ma>kud ralaih (object) useful objects according to the view of syara> (4) there is a replacement for exchange of goods. The legality of ijab qobul conditions there are three; (a) Do Not in intersperse with other words between ijab qobul, (b) people - the prescribed is run (seller and buyers) and (c) do not there separated the meaning the seller and buyers still no interaction about ijab qobul. Conditions of the legality of the seller and buyers there are four; (a) reached puberty understanding. (b) Moslems, this condition specifically for buyers in certain objects objects (c) no objects or items in chairman voterâ (ma>kud alaih) and (d) not wasted (waste), the will of their own and there is no compulsion of the other party. Conditions of the legality of goods sold voterâ there are six; (a) must be holy (b) cannot be not to associate with something (c) cannot be in the limit time (d) its own, (e) can be known (seen), ( $f$ ) can be known to the quality and the weight. Various kinds of selling (business) in Islam, seen from the point of view of the two glass eyes of Islamic law there are two valid and cancel and from the eye of goods there are three (1) selling goods that appear, (2) selling mentioned the pharmacodynamic him in the promise and(3) selling things that are not there. In Islam in business provide current accounts allow to choose to cancel the marriage of selling (business) called khiar, there are three, namely; (1) khiar, assembly (2) khiar conditions (3) khiar disgrace. The wisdom of selling in Islam; (a) that selling (business) in Islam can be valuable social or helped against each other, will grow berbagain reward, (b) business in Islam is one of the ways to maintain cleanliness and halalnya items eaten for himself and his family, (c) business in Islam is the way to combat laziness, unemployment and extortion to others.
\end{abstract}

Keywords: Selling, Islamic Views 


\section{A. Pendahuluan}

Jual beli (bisnis) dimasyarakat merupakan kegiatan rutinitas yang dilakukan setiap waktu oleh semua manusia. Tetapi jual beli yang benar menurut hukum Islam belum tentu semua orang muslim melaksanakannya. Bahkan ada pula yang tidak tahu sama sekali tentang ketentutanketentuan yang di tetapkan oleh hukum Islam dalam hal jual beli (bisnis).

Di dalam al-Qur'an dan Hadist yang merupakan sumber hukum Islam banyak memberikan contoh atau mengatur bisnis yang benar menurut Islam. Bukan hanya untuk penjual saja tetapi juga untuk pembeli. Sekarang ini lebih banyak penjual yang lebih mengutamakan keuntungan individu tanpa berpedoman pada ketentuan-ketentuan hukum Islam. Mereka cuma mencari keuntungan duniawi saja tanpa mengharapkan barokah kerja dari apa yang sudah dikerjakan.

Setiap manusia yang lahir di dunia ini pasti saling membutuhkan orang lain, aka selalu melakukan tolongmenolong dalam menghadapi berbagai kebutuhan yang beraneka ragam, salah satunya dilakukan dengan cara berbisnis atau jual beli. Jual beli merupakan interaksi sosial antar manusia yang berdasarkan rukun dan syarat yang telah di tentukan. Jual beli diartikan "al-bai', al-Tijarah dan alMubadalah". Pada intinya jual beli merupakan suatu perjanjian tukar menukar barang atau benda yang mempunyai manfaat untuk penggunanya, kedua belah pihak sudah menyepakati perjanjian yang telah dibuat.

\section{B. Pembahasan}

\section{Pengertian Jual Beli}

Sebelum membahas jual beli secara mendalam, terlebih dahulu diketahui pengertian jual beli, sehingga pembaca mengetahui dengan jelas apa itu jual beli dan dapat mengetahui apa yang dimakdsud oleh penulis. Jual beli dalam istilah fiqh disebut dengan al-bai' yang berarti menjual, mengganti, dan menukar sesuatu dengan sesuatu yang lain. Lafal albai' dalam bahasa Arab terkadang digunakan untuk pengertian lawannya, yakni kata asy- 
syira (beli). Dengan demikian, kata al-bai' berarti jual, tetapi sekaligus juga berarti beli (Haroen, 2000:111). Jual beli atau bisnis menurut bahasa berasal dari kata (لبيع) ) bentuk jamaknya (البيو ع) dan konjungsinya adalah “ "باع-بيع-بيعا yang artinya menjual (al-Marbawy, t.th: 72). Menurut bahasa, jual beli berarti menukarkan sesuatu dengan sesuatu (Al-Jaziri, 2003:123).

Sedangkan menurut istilah yang dimaksud jual beli atau bisnis adalah:

a. Menukar barang dengan barang atau barang dengan uang dengan jalan melepaskan hak milik dari yang satu kepada yang lain atas dasar saling merelakan (Idris, $1986: 5)$.

b. Menurut Syekh Muhammad ibn Qâsim al-Ghazzi

$$
\begin{aligned}
& \text { واما شرعا فاً حسن ما قيل فى تعريفة انه تمليك مالية بمعاوضة باذن شرعي } \\
& \text { أوتمليك منفعة مباحة على التاً بيد بثمنى مالي لمركي }
\end{aligned}
$$

Menurut syara, pengertian jual beli yang paling tepat ialah memiliki sesuatu harta (uang) dengan mengganti sesuatu atas dasar izin syara, sekedar memiliki manfaatnya saja yang diperbolehkan syara untuk selamanya yang demikian itu harus dengan melalui pembayaran yang berupa uang (alGhazzi, t.th:30).

c. Menurut Imam Taqiyuddin dalam kitab Kiffayatul alAkhyar

$$
\text { مقابالة مال قابلين للتصر ف بايجاب و قبول على الوجه الما عذون فيه }
$$

Saling tukarharta, saling menerima, dapat dikelola (tasharruf) dengan ijab qobul, dengan cara yang sesuai dengan syara (Taqiyuddin, t.th:329).

d. Syeikh Zakaria al Anshari dalam kitabnya fath AlWahab

$$
\text { مقبا لة مال بمال على وجه مخصوص }
$$


Tukar-menukar benda lain dengan cara yang khusus (dibolehkan) (Zakariya, t.th:157).

e. Menurut Sayyid Sabiq dalam Kitabnya Figh Sunnah

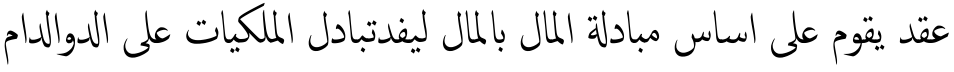

Penukaran benda dengan benda lain dengan jalan saling atau memindahkan hak milik dengan ada penggantinya dengan cara yang diperbolehkan (Sabiq, t.th:126).

f. Ada sebagian ulama memberikan pemaknaan tentang jual beli (bisnis), diantaranya; ulamak Hanafiyah “ Jual beli adalah pertukaran harta dengan harta (benda) berdasarkan cara khusus (yang di bolehkan) syara' yang disepakati". Menurut Imam nawawi dalam al-majmu' mengatakan "Jual beli adalah pertukaran harta dengan harta untuk kepemilikan". Menukar barang dengan barang atau barang dengan uang dengan jalan melepaskan hak milik atas dasar saling merelakan (Suhendi, 2007: 69-70).

\section{Dasar Hukum Jual Beli}

Dasar hukum jual beli adalah al-Qur'an dan alhadits, sebagaimana disebutkan dalam surat al-Baqarah ayat 275 :

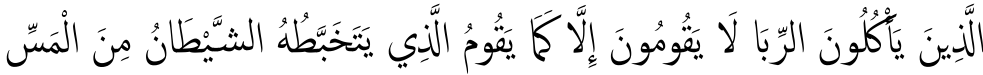

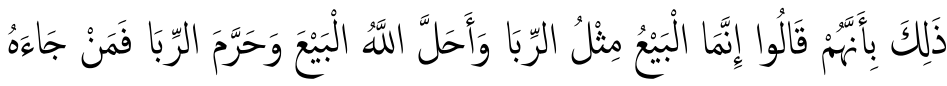

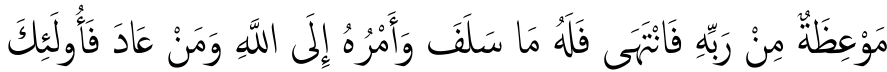

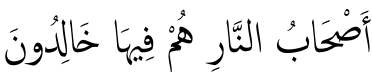

Orang-orang yang makan (mengambil) riba tidak dapat berdiri melainkan seperti berdirinya orang yang kemasukan syaitan lantaran (tekanan) penyakit gila keadaan mereka yang demikian itu, adalah disebabkan mereka Berkata (berpendapat), Sesungguhnya jual beli itu sama dengan riba, padahal Allah Telah menghalalkan jual beli dan mengharamkan riba. Orang-orang yang telah sampai kepadanya larangan Tuhannya, lalu terus 
berhenti (dari mengambil riba), maka baginya apa yang telah diambilnya dahulu (sebelum datang larangan); dan urusannya (terserah) kepada Allah. Orang yang kembali (mengambil riba), maka orang itu adalah penghuni-penghuni neraka; mereka kekal di dalamnya (Q.S.Al.Baqarah: 275)

Berdasarkan ayat tersebut dapat diambil pemahaman bahwa Allah telah menghalalkan jual beli kepada hamba-hamban-Nya dengan baik dan melarang praktek jual beli yang mengandung riba.

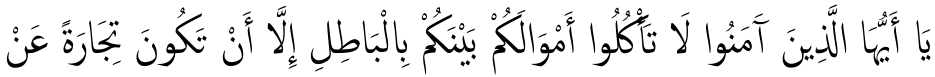

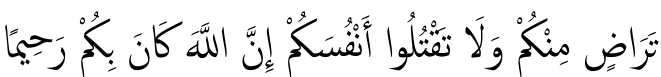

Hai orang-orang yang beriman, janganlah kamu saling memakan harta sesamamu dengan jalan batil, kecuali dengan jalan perniagaan yang berlaku dengan suka sama-suka diantara kamu, dan janganlah kamu membunuh dirimu sesungguhnya Allah adalah Maha Penyayang kepadamu. (Q.S. An-Nisa: 29).

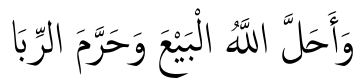

Padahal Allah telah menghalalkan jual-beli dan mengharamkan riba (QS. Al-Baqarah : 275).

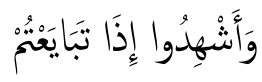

Dan persaksikanlah apabila kamu berjual-beli.(QS. Al-Baqarah: 282).

Allah mengharamkan kepada umat Islam memakan harta sesama dengan jalan batil, misalnya dengan cara mencuri, korupsi, menipu, merampok, memeras, dan dengan jalan lain yang tidak dibenarkan Allah., kecuali dengan jalan perniagaan atau jual beli dengan didasari atas dasar suka sama suka dan saling menguntungkan. Nabi SAW bersabda dalam hadis yang diriwayatkan oleh imam Bazzar yang berbunyi:

$$
\text { عن رفاعه بن رافع رضي الله عنه ان رسل الله صلى الله وسلم سئل : اى الى الكسب الرجل بيده وكل بيع مبرور (رواه البزر وصحه الحاك؟ }
$$




\section{Shobirin}

Dari Rif'ah Ibn Rafi sesungguhnya Rasulullah pernah ditanya "usaha apa yang paling baik? Rasulullah SAW menjawab "Usaha seseorang dengan tangannya sendiri dan setiap jual beli yang mabrur (jujur)". (H.R. Al-Al-Bazzar dan disahihkan oleh alHakim) (al-Shan'ani, t.th: 4).

Dalam Hadis lain yang diriwayatkan oleh Imam Muslim yang berbunyi, Rasulullah SAW bersabda:

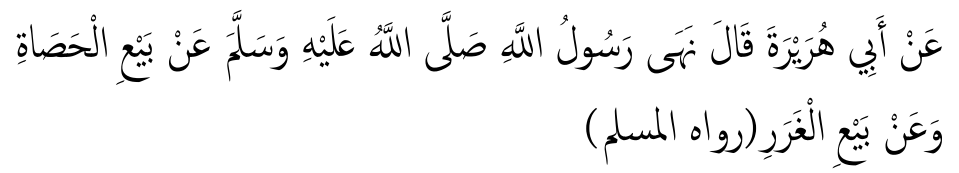

Dari Hurairah RA. Rasulullah SAW mencegah dari jual beli melempar kerikil dan jual beli Garar (H.R. Muslim) (Muslim, t.th : 156-157).

Berdasarkan hadist diatas bahwa jual beli hukumnya mubah atau boleh, namun jual beli menurut Imam Asy Syatibi hukum jual beli bisa menjadi wajib dan bisa haram seperti ketika terjadi ihtikar yaitu penimbunan barang sehingga persedian dan harga melonjak naik. Apabila terjadi praktek semacam ini maka pemerintah boleh memaksa para pedagang menjual baraang sesuai dengan harga dipasaran dan para pedagang wajib memenuhi ketentuan pemerintah didalam menentukan harga dipasaran serta pedangan juga dapat dikenakan saksi karena tindakan tersebut dapat merusak atau mengacaukan ekonomi rakyat.

Ulama telah sepakat bahwa jual-beli diperbolehkan dengan alasan bahwa manusia tidak akan mampu mencukupi kebutuhan dirinya, tanpa bantuan orang lain. Namun demikian, bantuan atau barang milik orang lain yang dibutuhkannya itu, harus diganti dengan barang lainnya yang sesuai dengan kesepakatan antara penjual dengan pembeli atau dengan alat tukar menukar yaitu dengan uang ataupun yang lainnya. Adapun dasar Ijma' tentang kebolehan Ijma' adalah sebagaimana yang telah diterangkan oleh Ibnu Hajar al-Asqolani di dalam kitabnya Fath al-Bari sebagai berikut :

$$
\text { وا جمع المسلمون على جوا ز البيع وا حكمة تقتضية لحا جة الانسا ن تتلو }
$$




$$
\text { بما يد صا حبه غاليا و صا حبه قد لا يبذ له }
$$

Telah terjadi ijma' oleh orang-orang Islam tentang kebolehan jual beli dan hikmah jual beli adalah kebutuhan manusia tergantung pada sesuatu yang ada ditangan pemiliknya terkadang tidak begitu saja memberikan kepada orang lain (al-Asqalani, t.th:287).

Berdasarkan dalil tersebut diatas, maka jelaslah bahwa hukum jual beli adalah jaiz ( boleh ). Namun tidak menutup kemungkinan perubahan status jual beli itu sendiri, semuanya tergantung pada terpenuhi atau tidaknya syarat dan rukun jual beli.

\section{Rukun dan Syarat Jual Beli dalam Islam}

Setelah diketahui pengertian dan dasar hukumnya, bahwa jual beli (bisnis) merupakan pertukaran harta atas dasar saling rela dan atas kesepakatan bersama. Suapaya bisnis yang kita lakukan itu halal, maka perlu memperhatikan rukun dan syarat jual beli (bisnis). Rukun secara bahasa adalah yang harus dipenuhi untuk sahnya suatu pekerjaan (DIKNAS, 2002:966). Sedangkan syarat adalah ketentuan (peraturan, petunjuk) yang harus diindahkan dan dilakukan ((DIKNAS, 2002:1114). Dalam buku Muhammad Amin Suma dijelaskan: rukun (Arab, rukn) jamaknya arkan, secara harfiah antara lain berarti tiang, penopang dansandaran, kekuatan, perkara besar, bagian, unsur dan elemen. Sedangkan syarat (Arab, syarth jamaknya syara'ith) secara literal berarti pertanda, indikasi dan memastikan.

Menurut istilah rukun diartikan dengan sesuatu yang terbentuk (menjadi eksis) sesuatu yang lain dari keberadaannya, mengingat eksisnya sesuatu itu dengan rukun (unsurnya) itu sendiri, bukan karena tegaknya. Kalau tidak demikian, maka subjek (pelaku) berarti menjadi unsur bagi pekerjaan, dan jasad menjadi rukun bagi sifat, dan yang disifati (al-maushuf) menjadi unsur bagi sifat (yang mensifati). Adapun syarat, menurut terminologi para fuqaha seperti diformulasikan Muhammad Khudlari Bek, ialah sesuatu yang ketidakadaannya mengharuskan (mengakibatkan) tidak adanya hukum itu sendiri. Hikmah dari ketiadaan syarat itu berakibat pula meniadakan 


\section{Shobirin}

hikmah hukum atau sebab hukum (Amin,2004:95). Dalam syari'ah, rukun, dan syarat sama-sama menentukan sah atau tidaknya suatu transaksi. Secara defenisi, rukun adalah suatu unsur yang merupakan bagian tak terpisahkan dari suatu perbuatan atau lembaga yang menentukan sah atau tidaknya perbuatan tersebut dan ada atau tidak adanya sesuatu itu (Dahlan, 1996:.1510).

Definisi syarat berkaitan dengan sesuatu yang tergantung padanya keberadaan hukum syar'i dan ia berada di luar hukum itu sendiri, yang ketiadaannya menyebabkan hukum pun tidak ada (Dahlan, 1996: 1691). Perbedaan antara rukun dan syarat menurut ulama ushul fiqih, yaitu rukun merupakan sifat yang kepadanya tergantung keberadaan hukum dan ia termasuk dalam hukum itu sendiri, sedangkan syarat merupakan sifat yang kepadanya tergantung keberadaan hukum, tetapi ia berada di luar hukum itu sendiri (Dahlan, 1996: 1692). Misalnya, rukuk dan sujud adalah rukun shalat. la merupakan bagian dari shalat itu sendiri. Jika tidak ada rukuk dan sujud dalam shalat, maka shalat itu batal, tidak sah. Syarat shalat salah satunya adalah wudhu. Wudhu merupakan bagian di luar shalat, tetapi dengan tidak adanya wudhu, shalat menjadi tidak sah. Menurut jumhur ulamak rukun jual beli itu ada empat (Zakaria, t.th:158), yaitu:

Pertama, Akad (ijab qobul), pengertian akad menurut bahasa adalah ikatan yang ada diantara ujung suatu barang. Sedangkan menurut istilah ahli fiqh ijab qabul menurut cara yang disyariatkan sehingga tampak akibatnya (al-Zuhaily, t.th:115).

Menurut Prof. Hasbi Ash-Shiddiqy aqad secara bahasa :

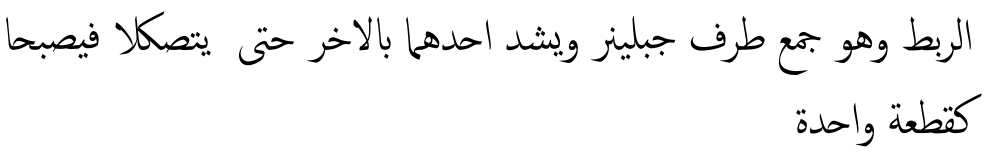

Al Rabt (mengikat) yaitu mengumpulkan dua tepi tali dan mengikat salah satunya dengan yang lain, sehingga bersambung, lalu keduanya menjadi sebagai sepotong benda (1979: 21).

Sedangkan aqad menurut istilah: 


\section{ارتباط الايجاب بقبول على وجه مشروع يثيت القراضى}

(Perkataan antara ijab qabul dengan cara yang dibenarkan oleh syara' yang menetapkan kedua belah pihak) (Hasby,1979 : 21).

Mengucapkan dalam akad merupakan salah satu cara lain yang dapat ditempuh dalam mengadakan akad, tetapi ada juga dengan cara lain yang dapat menggambarkan kehendak untuk berakad para ulama menerangkan beberapa cara yang ditempuh dalam akad diantaranya:

1). Dengan cara tulisan, misalnya, ketika dua orang yang terjadi transaksi jual beli yang berjauhan maka ijab qabul dengan cara tulisan (kitbah).

2). Dengan cara isyarat, bagi orang yang tidak dapat melakukan akad jual beli dengan cara ucapan atau tulisan, maka boleh menggunakan isyarat. Sehingga muncullah kaidah:

$$
\text { الاشارة المعهودة لاخرش كالبيان باللسان }
$$

isyarat bagi orang bisu sama dengan ucapan lidah (Suhendi, 2007:49).

3). Dengan cara ta'ahi (saling memberi), misalnya, seseorang melakukan pemberian kepada orang lain, dan orang yang diberi tersebut memberikan imbalan kepada orang yang memberinya tanpa ditentukan besar imbalan.

4). Dengan cara lisan al-hal, menurut sebagian ulama mengatakan, apabila seseorang meninggalkan barang-barang dihadapan orang lain kemudian orang itu pergi dan orang yang ditinggali barang-barang itu berdiam diri saja hal itu dipandang telah ada akad $i d a^{\prime}$ (titipan) antara orang yang meletakkan barang titipan dengan jalan dalalah al hal.

Dengan demikian akad ialah ikatan kata antara penjual dan pembeli. Jual beli belum dikatakan sah sebelum ijab dan qobul dilakukan sebab ijab qabul menunjukkan kerelaan (keridhaan). Ijab qabul boleh dilakukan dengan lisan atau tulis. Ijab qabul dalam bentuk perkataan atau dalam bentuk perbuatan yaitu saling memberi (penyerahan barang dan penerimaan uang). Pada dasarnya akad bapat 


\section{Shobirin}

dilakukan dengan lisan langsung tetapi bila orang bisu maka ijab qobul tersabut dapat dilakukan dengan surat menyurat yang pada intinya mengandung ijab qobul.

Kedua, orang yang berakad (subjek)

dua pihak terdiri dari bai'(penjual) dan mustari (pembeli). Disebut juga aqid, yaitu orang yang melakukan akad dalam jual beli, dalam jual beli tidak mungkin terjadi tanpa adanya orang yang melakukannya, dan orang yang melakukan harus:

1). Beragama Islam, syarat orang yang melakukan jual beli adalah orang Islam, dan ini disyaratkan bagi pembeli saja dalam benda-benda tertentu. Misalnya, seseorang dilarang menjual hamba sahaya yang beragama islam sebab besar kemungkinan pembeli tersebut akan merendahkan abid yang beragama islam. Sedangkan Allah melarang orang0orang mukmin memberi jalan kepada orang kafir untuk merendahkan mukmin, dalam firmannya:

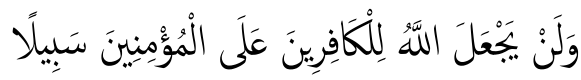

Dan Allah sekali-kali tidak akan memberi jalan kepada orangorang kafir untuk memusnahkan orang-orang yang beriman. (QS. An-Nisa:141)

2). Berakal, yang dimaksud dengan orang yang berakal disini adalah orang yang dapat membedakan atau memilih mana yang terbaik baginya. Maka orang gila atau bodoh tidak sah jual belinya, sekalipun miliknya sendiri. Sebagaiman firman Allah dalam surat An-Nisa: 5

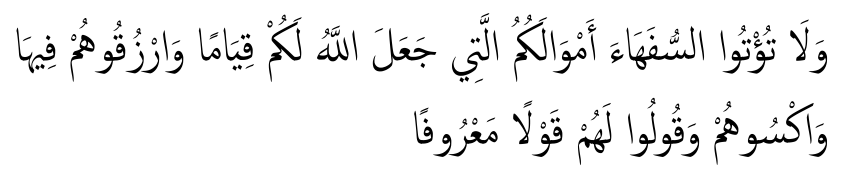

"Dan janganlah kamu serahkan kepada orang-orang yang belum sempurna akalnya harta (mereka yang ada dalam kekuasaanmu) yang dijadikan Allah sebagai pokok kehidupan, berilah mereka belanja dan pakaian (dari hasil harta itu) dan ucapkanlah kepada mereka kata-kata yang baik" (QS. AnNisa:5) 
3). Dengan kehendaknya sendiri, yang dimaksud dengan kehendaknya sendiri yaitu bahwa dalam melakukan perbuatan jual beli tidak dipaksa. Hal ini berdasarkan Hadis nabi Muhammad SAW

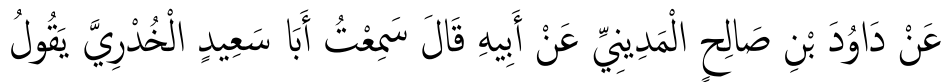

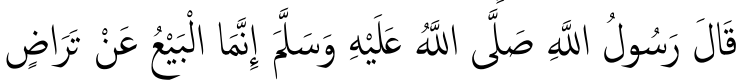

"Dari Daud Ibn Salih al-Madani dari ayahnya ia berkata "saya mendengar Abi Said al-Khudri berkata bahwa Rasulullah SAW bersabda "Sesungguhnya jual beli itu berdasarkan dari adanya saling kerelaan" (HR. Ibnu Majah) (Majah, t.th:737).

4). Baligh, baligh atau telah dewasa dalam hukum Islam batasan menjadi seorang dewasa bagi laki-laki adalah apabila sudah bermimpi atau berumur 15 tahun dan bagi perempuan adalah sesudah haid.

5). Keduanya tidak mubazir, yang dimaksud dengan keduanya tidak mubazir yaitu para pihak yang mengikatkan diri dalam perjanjian jual beli tersebut bukanlah manusia yang boros (mubazir). Sebagaimana disebutkan dalam al-Qur' an surat an-Nisa' ayat 5 tersebut di atas.

Ketiga, ma'kud 'alaih (objek) untuk menjadi sahnya jual beli harus ada ma'qud alaih yaitu barang menjadi objek jual beli atau yang menjadi sebab terjadinya perjanjian jual beli (Chairuman dan Suhwardi, 1996: 37). Barang yang dijadikan sebagai objek jual beli ini harus memenuhi syaratsyarat sebagai berikut:

1). Bersih barangnya, maksudnya yaitu barang yang diperjual belikan bukanlah benda yang dikualifikasikan kedalam benda najis atau termasuk barang yang digolongkan diharamkan. Hal ini berdasarkan hadis Nabi Muhammad SAW:

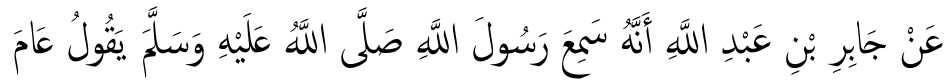

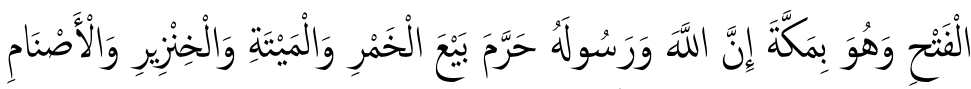

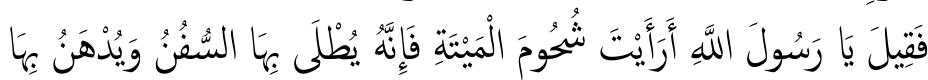




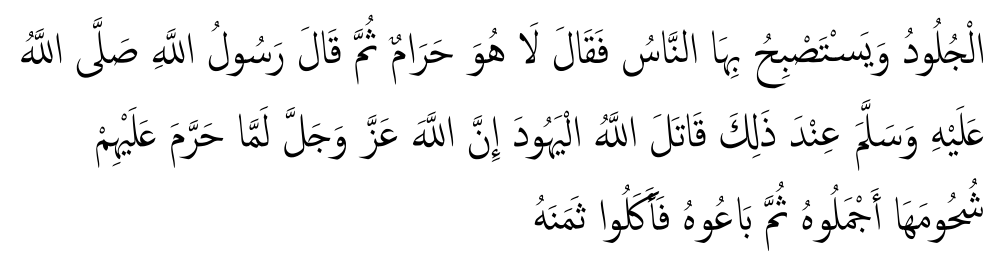

Dari Jabir Ibn Abdillah, bahwa ia mendengar Rasulullah SAW bersabda pada tahun kemenangan Makkah: "Sesungguhnya Allah telah melarang (mengharamkan) jual-beli arak, bangkai, babi dan patung" lalu seseorang bertanya "bagaimana dengan lemak bangkainya, karena dipergunakan untuk mengecat kayu dan minyaknya untuk lampu penerangan? Kemudian Rasulullah SAW menjawab "Mudah-mudahan Allah melaknat orang-orang yahudi karena sesungguhnya Allah telah mengharamkan lemak bangkai pada mereka, tetapi menjadikannya, menjualnya serta memakannya (hasilnya) (Muslim,t.th: 689).

Dalam hadis di atas menurut Syafi'iyah diterangkan bahwa arak, bangkai, babi dan patung adalah haram dijual belikan karena najis, adapun berhala jika dipecahpecah menjadi batu biasa boleh dijual sebab dapat digunakan untuk membangun gedung atau yang lainnya (Suhendi,2007:72).

2). Dapat dimanfaatkan, maksudnya yaitu barang yang diperjual belikan harus ada manfaatnya sehingga tidak boleh memperjual belikan barang-barang yang tidak bermanfaat.

3). Milik orang yang melakukan aqad, maksudnya bahwa orang yang melakukan perjanjian jual beli atas sesuatu barang adalah pilihan sah barang tersebut dan atau telah mendapat izin dari pemilik sah barang tersebut. Dengan demikian jual beli barang yang dilakukan oleh yang bukan pemilik atau berhak berdasarkan kuasa si pemilik dipandang sebagai perjanjian yang batal (alJaziri, 2003:103).

4). Mengetahui, maksudnya adalah barang yang diperjual belikan dapat diketahui oleh penjual dan pembeli dengan jelas, baik zatnya, bentuknya, sifatnya dan harganya. Sehingga tidak terjadi kekecewaan diantara kedua belah pihak. 
5). Barang yang di aqadkan ada ditangan, maksudnya adalah perjanjian jual beli atas sesuatu barang yang belum ditangan (tidak berada dalam kekuasaan penjual) adalah dilarang, sebab bisa jadi barang sudah rusak atau tidak dapat diserahkan sebagaimana telah diperjanjikan (Chairuman dan Suhwardi, 1996: 40).

6). Mampu menyerahkan, maksudnya adalah keadaan barang haruslah dapat diserah terimakan. Jual beli barang tidak dapat diserah terimakan, karena apabila barang tersebut tidak dapat diserah terimakan, kemungkinan akan terjadi penipuan atau menimbulkan kekecewaan pada salah satu pihak.

Benda yang diperjual belikan dapat mencakup barang atau uang, sifat benda harus dapat dinilai, yakni benda-benda yang berharga dan dapat dibenarkan penggunaanya menurut syara'. Benda-benda seperti alkohol, babi, dan barang terlarang lainnya haram diperjual belikan sehingga jual beli tersebut dipandang batal jika dijadikan harga tukar menukar, maka jual beli tersebut dianggap fasid (Masduki, 1987:5).

Keempat, ada nilai tukar pengganti barang, nilai tukar pengganti barang, yaitu sesuatu yang memenuhi tiga syarat; bisa menyimpan nilai (store of value), bisa menilai atau menghargakan suatu barang (unit of account) dan bisa dijadikan alat tukar (medium of exchange).

Empat rukun tersebut, memuat beberapa syarat yang harus di penuhi dalam juala beli (bisnis), yaitu syarat sahnya ijab qobul dalam kitab fiqh disebutkan minimal ada tiga; (a) Jangan di selingi dengan kata-kata lain antar ijab qobul, (b) Orang - orang yang berakad (penjual dan pembeli ) dan (c) Jangan ada yang memisahkan maksudnya penjual dan pembeli masih ada interaksi tentang ijab qobul.

Syarat sahnya penjual dan pembeli sebagai berikut; (a) baligh berakal agar tidak mudah ditipu orang. "Dan janganlah kamu berikan hartamu kepada orang-orang yang bodoh". (an-Nisaa'/4 : 5), (b) beragama Islam, syarat ini khusus untuk pembeli dalam benda benda tertentu. Misalnya, dilarang menjual hamba yang beragama Islam kepada orang kafir, karena di takutkan pembeli merandahkan 


\section{Shobirin}

orang yang beragama Islam. Sebagimana firman Allah: "Dan Allah sekali-kali tidak akan memberi jalan kepada orangorang kafir untuk memusnakan orang-orang yang beriman".(anNisaa' / 4:141), (c) ada benda atau barang yang di perjualkan belikan (ma'kud alaih) dan (d) tidak mubazir (pemborosan) dan kehendak sendiri tidak ada paksaan dari pihak lain.

Syarat sahnya barang yang dijual belikan diantaranya; (a) harus suci dan tidak terkena dengan najis, seperti anjing, babi dan kotoran hewan, kecuali kondisi dharurah dan ada asas manfaatnya. Misalanya, kotoran hewan untuk pupuk tanaman, anjing untuk keamanan, (b) tidak boleh mengkait-kaitkan dengan sesuatu, seperti, apabila ayahku meninggal, aku akan menjual motor ini, (c) tidak boleh di batasi waktunya, penjual tidak boleh mensyaratkan atau ketentuan untuk membayar tetapi hak itu merupakan hak dari pembeli karena itu salah satu sebab kepemilikan, (d) barang dapat diserahkan setelah kesepakatan akad, (e) barang yang diperjual belikan milik sendiri, akad jual beli tidak akan sah apabila barang tersebut hasil mencuri atau barang titipan yang tidak diperintahkan untuk menjualkan, (f) barang yang diperjual belikan dapat diketahui (dilihat), (g) barang yang diperjual belikan harus diketahui kualitasnya, beratnya, takarannya dan ukurannya, supaya tidak menimbulkan keraguan.

Ditinjau dari segi benda yang dijadikan obyek jual beli dapat dikemukakan pendapat Imam Taqiyuddin bahwa jual beli dibagi menjadi tiga bentuk, yaitu jual beli (1) jual beli benda yang kelihatan, (2) jual beli yang disebutkan sifat-sifatnya dalam janji dan (3) jual beli benda yang tidak ada (Taqiyuddin, t.th: 329). Jual beli benda yang kelihatan ialah pada waktu melakukan akad jual beli benda atau barang yang diperjual belikan ada di depan penjual dan pembeli, hal ini lazim dilakukan masyarakat banyak, seperti membeli beras di pasar dan boleh dilakukan. Jual beli yang disebutkan sifat-sifatnya dalam perjanjian ialah jual beli salam (pesanan). Menurut kebiasaan para pedagang, salam adalah untuk jual beli yang tidak tunai (kontan), salam pada awalnya berarti meminjamkan barang atau sesuatu yang seimbang dengan harga tertentu, maksudnya ialah 
perjanjian sesuatu yang penyerahan barang-barangnya ditangguhkan hingga masa tertentu, sebagai imbalan harga yang telah ditetapkan ketika akad. Jual beli benda yang tidak ada serta tidak dapat dilihat ialah jual beli yang dilarang oleh agama Islam, karena barangnya tidak tentu atau masih gelap, sehingga dikhawatirkan barang tersebut diperoleh dari curian atau barang titipan yang akibatnya dapat menimbulkan kerugian salah satu pihak.

Di samping itu, ada beberapa syarat lain berkaitan dengan jual beli, yaitu berkaitan dengan akad salam ( pesanan) (a) sifatnya harus memungkinkan dapat dijangkau pembeli untuk dapat ditimbang atau diukur, (b) dalam akad harus disebutkan kualitas dari barang yang akan diperjual belikan, (c) barang yang di serahkan sebaiknya barang yang di perjual belikan dipasar dan (d) harga hendaknya disetujui pada saat ditempat akad berlangsung. Apabila dalam akad salam (pesanan) penjual dan pembeli tidak melaksanakan salah satu syarat yang telah ditentukan maka akad jual beli itu belum dikatakan sah dalam syara' yang berlaku.

\section{Macam-Macam Jual Beli dalam Islam}

Macam-macam jual beli (bisnis) dalam Islam, dapat di lihat pada dua sudut pandang yaitu dari kaca mata hukum Islam dan dari kaca mata barang yang di perjual belikan. Bisnis dilihat dari kaca mata hukum Islam di bagi menjadi dua macam, yaitu jual beli (bisnis) yang sah menurut hukum Islam dan jual beli yang batal menurut hukum Islam.

Jual beli (bisnis) yang dapat dibatalkan menurut hukum Islam, yaitu; (a) jual beli barang yang di haramkan,

$$
\begin{aligned}
& \text { عن جابر رض آن رسول الله ص م قال إن الله ورسوله حرم بيع المثر و } \\
& \text { الميته والمنزير والاصنام (رواه البخارى ومسلم) }
\end{aligned}
$$

"Dari jabir r.a Rasulullah, bersabda sesungguhnya Allah dan Rasul-Nya telah mengharamkan menjual arak,bangkai,babi dan berhala" (HR Bukhari dan Muslim)

(b) Jual beli sperma (mani) hewan. Hukum Islam mebolehkan untuk menjual daging kambing yang belum di kuliti dengan ukuran timbang ,dan sama halnya dengan di bolehkan menjual ayam sembelihan dengan kotorannya masih di 


\section{Shobirin}

dalam perut ayam tersebut (Abdurrahman, 2004: 40). (c) Jual beli dengan perantara (al-wasilat), melalui perantara artinya memesan barang dengan akad jual membeli yang belum sempurna membayarnya tetapi tiba tiba ia mundur dari hak akad. Para ulama' memperbolehkan jual beli dengan membayar dahulu agar barang tersebut tidak di beli oleh orang lain. (d) Jual beli anak binatang yang masih berada di perut induknya karena barangnya belum ada jadi tidak di bolehkan.(e) Jual beli muhaqallah/baqallah tanah, sawah dan kebun maksudnya jual beli tanaman yang masih diladang atau sawah yang belum pasti wujudnya, hal ini masih diragukan bisa mengakibatkan ketidak rilaan dari pembeli atau penyesalan dari penjual, termasuk kategori jual beli gharar. (f) Jual beli mukhadharah, yaitu menjual buah-buahan yang belum pantas untuk panen, di dilarang karena masih samar karena dapat dimungkinkan buah itu jatuh tertiup angin sebelum diambil oleh pembelinya atau busuk dan lain sebaginya. (g) Jual beli muammasah, yaitu jual beli secara sentuh menyantuh kain yang sedang dipajangkan, orang yang menyentuh kain tersebut harus membeli. (h) Jual beli dengan munabadzah, yaitu jual beli secara lempar melempar, maksudnya seperti pelelengan barang harga yang paling besar itu yang akan mendapatkan barang tersebut, hal ini ditakutkan adanya penipuan. (i) Jual beli muzaabanah, yaitu menjual barang yang basah dan yang kering, maksudnya barang yang diperjual belikan dicampur dan mengakibatkan tidak adanya keseimbangan barang.

$$
\begin{aligned}
& \text { عن أنس رض قال نهى رسول الله عن المحا قلة والمحا ضرة والملا مسة والمنا } \\
& \text { بذة والمزابنة (رواه البخا رى) }
\end{aligned}
$$

Dari Anas r.a ,ia berkata: Rosulullah SAW melarang jual beli muhaqallah, mukhadharah, mulammasah, munabazah, dan muzabannah.

Sedangkan jual beli ditinjau dari segi benda dibagi menjadi tiga macam. Pendapat ini dikemukakan oleh Imam Taqiyuddin, jual beli dibagi menjadi tiga bentuk, yaitu:

$$
\text { البيوع ثلا ثة ييع عين مشا هدة وبيع شئ مو صوف فى الد مة لم تشاهد }
$$


"Jual beli ada tiga macam yaitu:1) Jual beli barang yang kelihatan, 2) Jual beli yang disebutkan sifat-sfat nya dalam janji dan 3) Jual beli benda yang tidak ada.

Jual beli benda yang kelihatan maksudnya pada waktu melakukan akad jual beli antara pembeli dan penjual ada yang di perjual belikan ada di depan mata. Hal ini banyak masyarakat yang melakukannya, ini dibolehkan, contoh di pasar membeli beras. Tapi, juga ada praktek di masyarakat jual beli yang hanya menyebutkan sifatnya atau contohnya, hal ini dilakukan di masyarakat dalam jual beli pesan barang, misalnya, pesan makanan, disebut bai' salam dalam hukum Islam dibolehkan. Sedangakan jual beli yang barangnya belum ada atau sifatnya belum ada seperti membeli kacang dalam tanah, membeli ikan dalam kolam belum jelas, dalam hukum Islam tidak diperbolehkan. Kecuali bagi orangorang tertentu yang mempunyai keahlian dalam menaksir, maka diperbolehkan.

\section{Hak dan Kewajiban antara Penjual dan Pembeli}

Untuk menghindari dari kerugian salah satu pihak maka jual beli haruslah dilakukan dengan kejujuran, tidak ada penipuan, paksaan, kekeliruan dan hal lain yang dapat mengakibatkan persengketaan dan kekecewaan atau alasan penyesalan bagi kedua belah pihak maka kedua belah pihak haruslah melaksanakan apa yang menjadi hak dan kewajiban masing-masing, diantaranya: pihak penjual menyerahkan barangnya sedangkan pihak pembeli menyerahkan uangnya sebagai pembayaran. Hal lain yang perlu diperhatikan adalah hendaklah dilakukan penulisan dari transaksi tersebut. Sebagaiman firman Allah SWT:

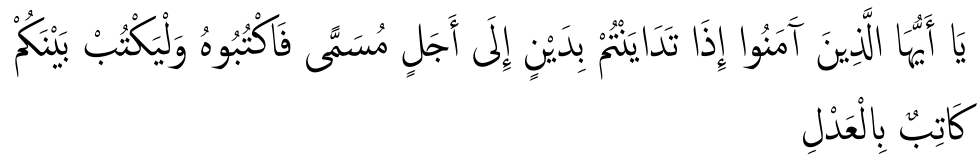

"Hai orang-orang yang beriman, apabila kamu bermu'amalah tidak secara tunai untuk waktu yang ditentukan, hendaklah kamu menuliskannya, dan hendaklah seorang penulis diantara kamu menuliskannya dengan benar" (QS. Al-Baqarah: 282). 
Selain penulisan untuk menghindari dari kemungkinan perselisihan, pengingkaran dan pemalsuan, maka diperlukan adanya saksi. Firman Allah:

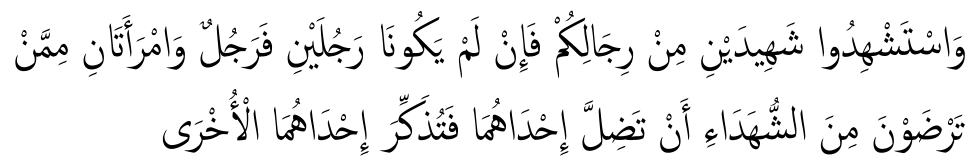

"Dan periksakanlah dengan dua orang saksi dari orangorang lelaki (diantaramu), jika tak ada dua orang lelaki, maka (boleh) seorng lelaki dan dua orang perempuan dari saksisaksi yang ridhai, supaya jika seorang lupa maka yang seorang mengingatkannya" (QS. Al-Baqarah: 282).

Dalam ayat tersebut dapatlah dipahami bahwa antara penjual dan pembeli mempunyai hak dan kewajiban, yang mana hak dan kewajiban tersebut harus dipenuhi oleh masing-masing pihak.

\section{Khiyar dalam Bisnis Islam}

Bisnis dalam Islam di berikan keleluasan untuk memilih untuk membatalkan akad jual beli (bisnis) atau meneruskan akad jual beli (bisnis) dalam hukum Islam dinamakan khiyar. Khiar adalah mencari kebaikan dari kedua perkara yaitu melangsungkan atau membatalkan (Sabiq,1988:100). Sedangkan khiyar dalam jual beli menurut hukum Islam adalah diperbolehkannya memilih apakah jual itu diteruskan apa dibatalkan karena suatu hal (suhendi, 2007:83). Adapun dasar hukum khiyar di jelaskan pada hadits sebagai berikut :

$$
\begin{aligned}
& \text { عن ابن عمر يقو ل : قال رسو ل الله صلى الله عليه و سلم :كل بيعين لا } \\
& \text { يبع بينها حتى يتفر قا الا بيع الخيا ر لئر }
\end{aligned}
$$

Dari Ibnu Umar, ia berkata : Rosulullah SAW bersabda : masingmasing penjual dan pembeli, tidak akan terjadi jual beli dianatara mereka sampai mereka berpisah, kecuali dengan jual beli khiyar (Muslim,t.th:22).

Khiyar secara umum dibagi menjadi tiga, yaitu:

Pertama, Khiyar Majelis, artinya antara penjual dan 
pembeli boleh memilih akan melanjutkan jual beli atau membatalkannya saat teransaksi masih berlangsung ditempat teransaksi, apabila akad dalam jual beli telah dilaksanakan oleh pihak penjual dan pembeli maka kedua belah pihak boleh meneruskan atau membatalkan selama keduanya masih berada di tempat akad (Sabiq, 1988:101). Rasulullah SAW bersabda :

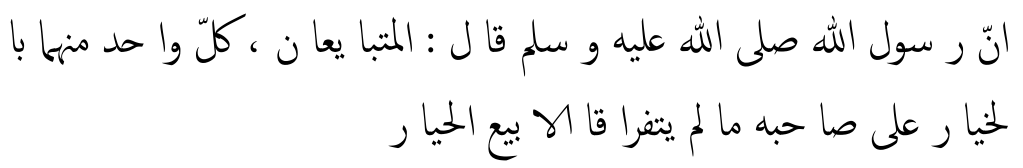

Sesungguhnya Rosulullah SAW pernah bersabda : penjual dan pembeli, masing-masing mempunyai hak atau kesempatan berfikir sebelum berpisah mengenai jadi atau tidaknya jual beli.

Khiyar majelis dinyatakan gugur apabila dibatalkan penjual dan pembeli setelah akad, apabila salah satu dari keduanya membatalkan maka khiyar yang lain masih berlaku dan khiyar terputus apabilah salah satu dari keduanya telah meninggal dunia (Sabiq, 1988: 209).

Kedua, Khiyar Syarat, yaitu penjual dan pembeli di dalamnya disyaratkan sesuatu boleh penjjual maupun pembeli, misalnya pakaian jika cocok atau pas dipakai di beli kalau tidak pas atau tidak cocok boleh di kembalikan. Dalam penjualan yang di dalamnya disyaratkan sesuatu yang baik oleh penjual maupun pembeli (Suhendi,2007:84).

Sebab-sebab berakhirnya khiyar syarat adalah sebagai berikut : (a) adanya pembatalan akad, (b) melewati batas waktu khiyar yang telah disepakati/ditetapkan. Ada perbedaan pendapat tentang batas waktu khiyar, menurut Imam Syafi'I dan Abu Hanifah berpendapat bahwa jangka waktu khiyar adalah tiga hari, sedangkan menurut Imam Malik jangka waktu khiyar adalah sesuai dengan kebutuhan (Sabiq,1988:102 ), (c) terjadi penambahan atau pengembangan dalam penguasaan pihak pembeli baik dari segi jumlah seperti beranak atau mengembang, (d) terjadi kerusakan pada objek akad. Jika kerusakaan tersebut terjadi dalam penguasaan pihak penjual maka akadnya batal dan berkhirlah khiyar. Namun apabila kerusakaan terjadi dalam 
penguasaan pihak pembeli maka berakhirlah khiyar namun tidak membatalkan akad dan (e) wafatnya Shohibul khiyar, ini menurut pendapat madzhab Hanafiyah dan Hambaliah. Sedangkan madzhab Syafi'iyah dan Malikiyah berpendapat bahwa hak khiyar dapat berpindah kepada ahli waris ketika shohibul khiyar telah wafat (Mas'adi,2002:111).

Ketiga, Khiar Aib, dalam jual beli ini disyaratkan kesempurnaan benda - benda yang dijual belikan, misalnya jika kita beli krudung satu kodi ternyata samapai rumah ada yang cacat boleh dikembalikan. Khiyar Aib (cacat) yaitu apabila barang yang telah dibeli ternyata ada kerusakan atau cacat sehingga pembeli berhak mengembalikan barang tersebut kepada penjual (Rasjid,1976:277). Hak yang dimiliki oleh salah seorang dari aqidain untuk membatalkan akad atau tetap melangsungkannya ketika menemukan cacat pada objek akad dimana pihak lain tidak memberitahukannya pada saat akad (Mas'adi,2002:112). Khiyar aib ini didasarkan pada hadits Uqbah Ibn Amir, r.a

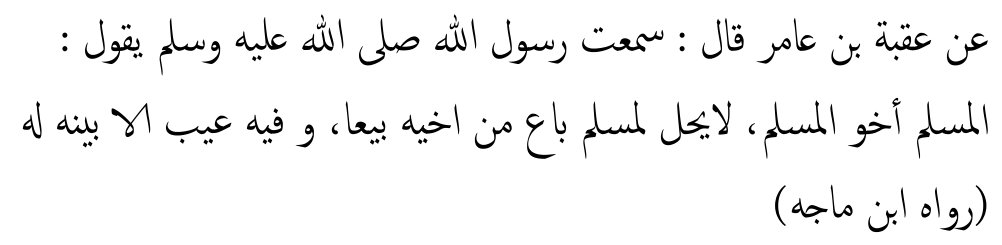

Dari Uqbah Ibn Amr berkata : saya mendengar Rosulullah SAW bersabda : seorang muslim adalah saudara bagi muslim lainnya, maka tidak halal seorang muslim menjual kepada saudaranya sesuatu yang mengandung kecacatan kecuali ia harus menjelaskan kepadanya.

Khiyar aib harus memenuhi persyaratan sebagai berikut; (a) Aib ( cacat) tersebut sebelum akad atau setelah akad namun belum terjadi penyerahan. Jika cacat tersebut terjadi setelah penyerahan atau terjadi dalam penguasaan pembeli maka tidak berlaku hak khiyar, (b) Pihak pembeli tidak mengetahui akad tersebut ketika berlangsung akad atau ketika berlangsung penyerahan. Jika pihak pembeli sebelumnya telah mengetahuinya maka tidak ada hak khiyar baginya (c) Tidak ada kesepakatan bersyarat bahwasanya penjual tidak bertanggung jawab terhadap segala cacat yang ada. Jika ada kesepakatan bersyarat seperti itu, maka hak khiyar bagi 
pembeli menjadi gugur.

Khiyar aib ini berlaku semenjak pembeli mengetahui cacat setelah berlangsungnya akad. Adapun batas waktu menuntut pembatalan akad terdapat perbedaan pendapat di kalangan fuqoha. Menurut fuqaha Hanafiyah dan Hanabilah, batas waktunya berlaku secara tarakhi (pihak yang dirugikan tidak harus menuntut pembatalan akad ketika ia mengetahui cacat tersebut). Sedang menurut fuqaha Malikiyah dan Syafi $\square$ iyah, batas waktunya berlaku secara faura (seketika, artinya pihak yang dirugikan harus menggunakan hak khiyar secepat mungkin, jika ia mengulur- ulur waktu tanpa alasan yang dapat dibenarkan maka hak khiyar gugur dan akad dianggap telah lazim / pasti).

Hak khiyar aib ini gugur apabila: (a) Pihak yang dirugikan merelakan setelah ia mengetahui cacat tersebut, (b) Pihak yang dirugikan sengaja tidak menuntut pembatalan akad, (c) Terjadi kerusakan atau terjadi cacat baru dalam penguasaan pihak pembeli dan (d) Terjadi pengembangan atau penambahan dalam penguasaan pihak pembeli, baik dari sejumlah seperti beranak atau bertelur, maupun dari segi ukuran seperti mengembang.

\section{Simpulan}

Bagi umat Islam yang melakukan bisnis dan selalu berpegang teguh pada norma-norma hukum Islam, akan mendapatkan berbagai hikmah diantaranya; (a) bahwa jual beli (bisnis) dalam Islam dapat bernilai sosial atau tolong menolong terhadap sesama, akan menumbuhkan berbagain pahala, (b) bisnis dalam Islam merupakan salah satu cara untuk menjaga kebersihan dan halalnya barang yang dimakan untuk dirinya dan keluarganya, (c) bisnis dalam Islam merupakan cara untuk memberantas kemalasan, pengangguran dan pemerasan kepada orang lain, (e) berbisnis dengan jujur, sabar, ramah, memberikan pelayanan yang memuaskan sebagai mana diajarkan dalam Islam akan selalu menjalin persahabatan kepada sesama manusia. 
Shobirin

\section{DAFTAR PUSTAKA}

Al-Qur'an, 1999, al-Qur'an dan Terjemahannya, Jakarta: Yayasan Penyelenggara penterjemeh / penafsiran al-Quran, Departemen Agama RI.

Al-Shan'ani, Muhammad Bin Ismail al-Amir al-Yamani, t.th, Subul as Salam, Juz X, Beirut: Darul Fikr.

Al-Ansari, Syeikh Abi Zakaria, t.th, Fath al-Wahab, Juz 1, Singapura: Sulaiman Mar'I.

Al-Zuhaily, Wahbah, t.th, al-Figh al islami wa adilah, Juz IV, Mesir: Dar Fikr.

Ash-Shiddiqiey, TM.Hasby, 1979, Pengantar Mu'amalah, Jakarta: Bulan Bintang

Al-Ghazzi, Muhammad ibn Qâsim, t.th, Fath al-Qarîb al-Mujî̀b, Indonesia: Dâr al-Ihya al-Kitab, al-Arabiah.

Al- Asqalani, Ibnu Hajar, t.th, Fath Al-Bari', Beirut: Daral- Fikr. Amin Suma, M., 2004, Hukum Keluarga Islam di Dunia Islam, Jakarta: Raja Grafindo.

Al-Jaziri, Abd.al-Rahman, 2003, Kitab Figh Ala al-Mazahib alArba'ah, Turki: Ikhla Wakif.

Abdurrahman al-Gharyani, Ash-shadiq, 2004, Fatwa muamalat as-asyaiah, Surabaya: Pustaka progressif

Ahmad, Idris, 1986. Fiqh al-Syafi'iyah, Jakarta: Karya Indah.

Abi Bakr Ibn Muhammad al-Husaini, Imam Taqiyuddin, t.th, Kifayatul al-Akhyar Juz I, Surabaya: Darul Ilmi.

Chairuman Pasaribu dan Suhwardi K. Lubis, 1996, Hukum Perjanjian dalam Islam, Jakarta: Sinar Grafika. 
Jual Beli dalam Pandangan Islam

Departemen Pendidikan Nasional,2002, Kamus Besar Bahasa Indonesia, Jakarta: Balai Pustaka.

Dahlan, Abdul Azis, (editor), 1996, Ensiklopedi Hukum Islam, Jilid 5,Jakarta: Ichtiar Barn van Hoeve.

Haroen, Nasrun,2000, Figh Muamalah, Jakarta: Gaya Media Pratama.

Imam Muslim, t.th, Shahih Muslim, Beirut: Darul Fikr

Ibnu Majah, t.th, Sunnah Ibnu Majah, Bandung: al-Ma'arif.

Masduki, Nana, 1987. Figh Mu'amalah Madiyah. Bandung: IAIN Sunan Gunung Djati

Mas'adi, A., Ghofron, 2002, Figh Mu'amalah Kontekstual, Jakarta: PT Raja Grafindo Persada.

Rasjid, Sulaiman, 1976, Fiqh Islam, Jakarta: Attahiriyah.

Suhendi, Hendi, 2007, Figh Muamalah, Jakarta: Raja Grafindo persada

Sabiq, Sayyid, 1997. Figh al-Sunnah. Beirut: Dar al-Fikr 